\title{
VERTENTES DA ESCRITA DE SI EM MAIS AO SUL DE PALOMA VIDAL
}

\section{ASPECTS OF SELF WRITING IN MAIS AO SUL BY PALOMA VIDAL}

\author{
Cinthia Maritz dos Santos Ferraz Machado' \\ Lucimara de Andrade ${ }^{2}$
}

\begin{abstract}
RESUMO: Na contemporaneidade, as questóes de representaçăo biográfica reacendemse, sobretudo, como questóes de escrita autoral ou escrita de si. Nessa perspectiva, novas vozes literárias surgem como enunciadoras de marcas autorais que desafiam o leitor ao proporem um pacto continuamente renovado, mesmo que falso, entre a ficçâo e o biografismo. A exemplo, podemos citar a habilidade de Paloma Vidal em manusear a voz autoral, a memória pessoal e o tom contido e intimista na procura pela identidade de uma pessoa confusa com as suas origens, assim como suas dúvidas, e reflexóes sobre deslocar-se ou o estar em trânsito, aspecto que constitui a força-motriz de sua criaçăo literária.
\end{abstract}

PALAVRAS-CHAVE: escrita de mulheres; escrita de si; memória; narrativas da modernidade; Paloma Vidal.

ABSTRACT: In contemporary times, issues of biographical representation emerge, above all, as questions of authorial writing or self-writing. In this perspective, new literary voices emerge as enunciators of authorial markings that challenge the reader by proposing a continually renewed pact, even if false, between fiction and biograph. For example, we can mention the ability of Paloma Vidal to handle the authorial voice, the personal memory and the restrained and intimate tone in the search for the identity of a person confused with his origins, as well as his doubts, and reflections on moving or being in transit, an aspect that is the driving force of his literary creation.

KEYWORDS: women's writing; self-writing; memory; narratives of modernity; Paloma Vidal.

1 Doutora em Estudos Literários pela Universidade Federal de Juiz de Fora, Mestre em Letras - Literatura, Cultura e Sociedade, pela Universidade Federal de Viçosa e graduada pela mesma instituiçăo.

2 Assessora científica da Fundaçâo de Amparo à Pesquisa do Estado de Sáo Paulo (FAPESP). Doutora pelo Programa de Pós-Graduaçáo em Estudos Literários da Faculdade de Letras da Universidade Federal de Minas Gerais, área de concentraçáo Teoria da Literatura e Literatura Comparada, linha de pesquisa Poéticas da Modernidade (2017). 


\section{INTRODUÇÃO}

A escrita de si como processo e reflexo do vivido promove uma reflexáo sobre o uso dos fragmentos de memória e recortes biográficos. O bricoleur surge nesse contexto como metáfora para a compreensáo e análise de algumas práticas de escrita realizadas na contemporaneidade. $O$ escritor, em seu processo de criaçâo e construçấo poética, assim como o bricoleur em seu processo de coleta e construçáo de um projeto próprio, acaba sempre colocando algo de si mesmo. E "ao utilizar resíduos e fragmentos de acontecimentos, histórias de um indivíduo ou de uma sociedade, ele năo só "fala" com eles, como também conta por meio deles" (CORRÊA; FRANÇA, 2014, p. 234). Nesse sentido, ao utilizar resíduos e fragmentos da memória, histórias de si, de outros ou de uma sociedade, o escritor estaria realizando um processo de reapropriaçâo e de ressignificaçâo e tal procedimento nos permite inferir que processos de elaboraçâo criativa săo perpassados por modos de subjetivaçăo.

A literatura, portanto, transforma e intensifica a linguagem comum, afastando-a sistematicamente da cotidiana. Assim como as demais acepçōes de linguagem (técnica, inspirada, emotiva, expressiva, entre outras), a linguagem literária náo é uma simples depuraçâo da linguagem utilitária. Ao transpor o mundo utilitário para o mundo da representaçăo, a obra literária despoja-o de sua contingência e torna-o, entăo, profundo e extremamente significativo. O processo de escrita literária, entăo, singulariza relaçôes e processos de criaçăo frente às demais aplicaçôes e usos da linguagem comum. Nesta trama verbal, tornam-se presentes e manifestos, o intelectual, o imaginativo e o emotivo, que de maneira coexistencial compactuam na obra.

A mençấo à especificidade da linguagem literária objetiva evocar aqui a consciência dramática dessa mesma linguagem. Ela renova, modifica e amplia nossas relaçôes habituais, tornando o objeto literário mais perceptível. A lida com uma linguagem de emprego diferenciado, engenhoso, encerra uma autoconsciência sobre o intensificado em relaçăo ao usual.

O exercício da escrita pode, entăo, revelar-se - dentre as diversas possibilidades ou as virtualidades de caminhos a serem seguidos pela criatividade artística - como experiência do vivido, entremeando-se, por vezes, no simulacro da biografia durante a conduçâo do fazer literário. A escrita de si, constituída por pedaços e deslocamentos da memória, năo deve reduzir-se, entretanto, a nenhum dos gêneros autorrepresentativos, uma vez que se consubstancia no exercício da "figura" do sujeito literário (latim figurare: traçar o perfil, o desenho).

Sabemos que a expressăo "sujeito literário" demarca, por assim dizer, o território masculinizado a que a Literatura é sujeita desde as sociedades antigas. A partir do momento em que a escrita feminina vai ganhando terreno, gradativamente o papel submisso da mulher vai sendo minimizado em um processo de crescente expansấo de sua voz e de temas abordados. E é ao tornar-se "sujeito" da escrita literária que a mulher, consequentemente, apresenta novos enfoques e novas percepçóes da condiçáo humana, sobretudo a feminina, frente a uma sociedade, ainda na contemporaneidade, majoritariamente patriarcal. Para este estudo, escolhemos a escritora Paloma Vidal, uma representativa voz das questóes aqui elencadas na produçăo literária brasileira do panorama atual. 
Paloma Vidal nasceu em Buenos Aires, Argentina, em 1975, e aos 2 anos de idade mudou-se com os pais (perseguidos pela ditadura na Argentina) para o Rio de Janeiro, onde passou a infância e a juventude. A escritora, no entanto, náo se naturalizou brasileira e a condiçấo de estar entre duas línguas e duas culturas distintas parece ter implicaçōes fortes em suas obras, tanto nas acadêmicas quanto nas literárias. Graduou-se em Letras e em Filosofia pela Universidade Federal do Rio de Janeiro, e em 2003 publicou seu primeiro livro de contos, intitulado Duas Mâos. Desde entấo, os temas abordados pela artista (em ambas as suas vertentes de atuaçăo) relacionam-se fortemente à sua história de vida, nos quais a autora debruça-se sobre motivos como exílio, viagens e deslocamento. Desse modo, o "estar em trânsito" é manifestado em diferentes instâncias de sua produçâo ficcional: territorial, político, cultural e linguístico.

Nessa perspectiva, o movimento entre diferentes culturas, línguas diversas e casas ocupadas ou (semi) abandonadas, retratado em obras como Mais ao Sul, parece revelar ao leitor as próprias contingências de vida da escritora. Em Mais ao Sul, uma compilaçăo de contos publicada em 2008, há duas etapas que remetem à problematizaçăo do contínuo entre-lugar e à ambiguidade cultural vivenciada pela(s) personagem(s). Os contos săo agrupados e divididos por subtítulos como "Viagens" e "Fantasmas". A primeira parte do livro, como o próprio nome evoca, traduz a sensaçáo de falta de um chăo em que se possa "plantar raízes", ao passo em que aborda as complicaçóes da política latino-americana. Na segunda parte, podemos encontrar relatos de mulheres que, de alguma forma, esperam pelo tempo de partir ou buscam encontrarem a si mesmas, emoldurando um momento em que a voz feminina se faz clara, sem concessóes.

Assim, em Mais ao Sul estăo configuradas, portanto, características marcantes do estilo da autora, como a constituiçăo de um ponto de vista majoritariamente feminino, ao passo em que fica também inscrita a investigaçâo ou autorreflexăo das próprias razōes da escrita. A ambiguidade cultural vivenciada pela autora se manifesta no nível mais profundo da consciência: o da linguagem. É com base nas experiências de deslocamento que Paloma Vidal tece reflexóes estéticas sobre a constituiçăo da identidade e da escrita em um contexto contemporâneo. Nesse sentido, buscaremos analisar em Mais ao Sul as relaçóes entre memória, escrita de si e deslocamento na constituiçâo de um sujeito fragmentário, em constante trânsito nas esferas territorial, linguística e temporal.

\section{SUGESTÃO DE TÍTULO: TERRITORIALIDADES E LINGUAJAMENTO EM MAIS AO SUL}

O tema do deslocamento aparece na obra de Paloma Vidal de modo preponderante, demonstrando se configurar na produçáo artística da escritora como mais do que um motivo literário em especial. A partir da trajetória pessoal da autora - o veio artístico e o acadêmico -, é importante entendermos os processos de produçăo do pensamento crítico-literário, no panorama das discussóes atuais que o circundam, para que possamos realizar algumas leituras da obra. Nesse sentido, é impositivo que reflitamos năo somente sobre o processo de "deslocamento físico" de Paloma Vidal, mas também sobre o "produto final" resultante desse deslocamento. É preciso, pois, que possamos pensar sobre as instâncias da escrita, e nâo apenas nos aspectos autorais. Para tanto, traçaremos alguns delineamentos teórico-críticos a respeito do espaço social. 
A questăo do território tem sido problematizada nas Ciências Sociais principalmente a partir da "crise pós-moderna" contemporânea, que tem retomado as discussóes sobre o tema pela perspectiva da dimensâo espacial da sociedade. Segundo Haesbaert (2007), filósofos e cientistas, até meados de 1960, haviam negligenciado o espaço em suas análises, ficando somente aos geógrafos o encargo do tratamento desse assunto.

A partir de Michel Foucault (1967) é que pensadores e pesquisadores, como sociólogos e antropólogos, têm se dedicado ao tema e passado a colocá-lo na pauta do pensamento científico. O processo de mundializaçăo fez com que se tornassem urgentes e cada vez mais crescentes as reflexōes sobre os espaços fronteiriços (fluidez e flexibilidade), segregaçáo, espaços mais ou menos "concretos", identidade, cultura, pertencimento, entre outras questóes. Nesse sentido, os estudos sobre territorializaçâo surgem como redescoberta de um conceito para que se possa falar do seu desaparecimento (HAESBAERT, 2007) na contemporaneidade; ou para que se possa problematizá-lo.

Logo, quando mencionamos território para falar de "desterritorializaçăo" (enfraquecimento das concepçóes de espaço e seus limites), devemos considerar a polissemia do conceito, que se pode relacionar ao político: desterritorializaçấo ligada à fragilidade atual e crescente das fronteiras (estatais); ou ao simbólico: desterritorializaçăo como hibridizaçâo cultural, que dificulta o reconhecimento de identidades claramente definidas.

Nesse sentido, a territorialidade, além de incorporar uma dimensăo estritamente política, alcançando, portanto, o reflexo de "desterritorializaçăo", diz respeito também às relaçōes econômicas e culturais, pois está ligada ao modo como as pessoas utilizam a terra, como se organizam no espaço e como dăo significado ao lugar. No entanto, a territorialidade, como um componente do poder, năo pode ser traduzida apenas como um meio para criar e manter a ordem, mas também como uma possibilidade de experimentarmos o mundo e o dotarmos de significado. Portanto, todo território é simultaneamente e em diferentes combinaçōes ou instâncias, funcional e simbólico, já que o espaço pode ser usado tanto para realizar "funçôes" quanto para produzir "significados".

Enfatizamos o uso do termo "desterritorializaçăo" entre aspas para ponderarmos que este se remete a mais do que a perda ou o desaparecimento/enfraquecimento dos territórios. Na contemporaneidade, é necessário discutirmos a complexidade dos processos de (re)territorializaçâo em que estamos envolvidos, por construirmos modernamente territórios muito mais múltiplos ou complexos. Compreender o processo de "desterritorializaçấo" implica, atualmente, em reconhecer o caráter imanente da (multi)territorializaçâo na vida dos indivíduos e dos grupos sociais, pois, "mais do que a desterritorializaçâo desenraizadora, manifesta-se um processo de reterritorializaçâo espacialmente descontínuo e extremamente complexo" (HAESBAERT, 1994, p. 214).

O indivíduo, em suas relaçóes sociais mais ou menos ampliadas, vive a recolocaçâo de saberes e língua/linguagens, o que torna a globalizaçăo "a imagem de um projeto civilizador" (MIGNOLO, 2003, p. 377).

As histórias locais (que exportam projetos globais ou os importam e os transformam - processo de mundializaçáo) situam as diferenças e as incorporam na história e na memória. É dado esse processo complexo que ocorre no sujeito a sensaçăo de multiplicidade de sentimentos de pertencimento, ou a constante re-elaboraçâo das relaçôes de pertencimento, identidade e território. 
É nesse sentido que a problematizaçáo do espaço tem alcançado o âmbito das representaçóes estéticas na atualidade (ou no panorama contemporâneo), náo se restringindo apenas ao espaço teórico-discursivo das Ciências Sociais. Na literatura atual, a questáo do espaço ou do "estar no mundo" tem aparecido frequentemente sob a forma memorialística em temas como viagens, onde se abordam as questóes de deslocamento. A ficçáo de Paloma Vidal nos parece ser reveladora e ilustrativa das questôes políticas e de identidade que envolvem o espaço social por refletir uma certa angústia, tangenciada pela "falta de châo" e pela reflexâo permanente sobre a condiçấo da existência e do pertencer.

A literatura, e em especial a narrativa ficcional, tem o poder de refletir sobre questôes específicas porque sua história real é justamente a das revoltas específicas, conforme Pascale Casanova (2002). O universo literário, segundo a pesquisadora, é composto dos atos de violência, das invençōes de formas, processos e línguas, e principalmente, de todas as subversóes da ordem literária, de modo que "a literatura é uma espécie de criaçăo, ao mesmo tempo irredutivelmente singular e, no entanto, inelutavelmente coletiva, de todos os que criaram, reinventaram ou se reapropriaram do conjunto de soluçôes disponíveis para mudar a ordem do mundo literário" (CASANOVA, 2002, p. 217). Nesse sentido, a obra surge como um universo estético a partir do qual é possível perscrutarmos a constituiçăo subjetivo-literária da existência e do pertencer.

Em Mais ao Sul, a voz feminina retoma o projeto iniciado em As duas máos (2003), cujas personagens, mediante um universo masculino de abandono afetivo, elaboram um mecanismo compensatório: a construçáo de um cenário idealizado e amenizador de seu desamparo. A obra mais recente, porém, surge com vários acréscimos: ao retratar mulheres desenraizadas, Paloma Vidal relata as complicaçóes políticas, as dores de um mundo feérico, a recuperaçáo de laços ou parte de uma história familiar nunca compartilhada, a angústia da identidade e a sensaçáo da falta de pertencimento a um "chăo".

Chama atençăo, inicialmente, a capa do livro: a imagem de uma revoada de pássaros no céu, a pintalgar um céu escuro com inúmeros espécimes. Năo raro, ao longo de todo o livro, mas, principalmente na primeira parte, a narradora menciona uma leitura sobre a migraçáo das aves, soltando aqui e acolá notas e dados sobre o assunto ao tempo em que conta a história da migraçăo de sua família (a história de seus avós). A leitura sobre pássaros e suas viagens permite à escritora tecer reflexôes a respeito dos seus ancestrais e das experiências vividas por estes, bem como interpretar as suas próprias, como motivadas por um quê de ancestralidade, tal como a das aves que migram:

Leio que há um forte componente genético no tempo e na rota da migraçăo dos pássaros, mas isso é muitas vezes modificado por influência do ambiente. Assim, um pássaro pode mudar de rota por causa de uma barreira geográfica, como uma grande cadeia de montanhas, fazendo um desvio que aumentará em até $20 \%$ o tamanho de sua viagem, ainda assim vantajosa. No entanto, pode ocorrer também que alguns pássaros sigam rotas que refletem mudanças históricas herdadas e que hoje estăo longe de ser as mais adequadas.

Leio que o comportamento migratório se encontra também em aves residentes, que apresentam, a cada estaçăo, uma espontânea urgência de migrar. Esse comportamento varia de espécie para espécie, mas a pesquisa sugere que a urgência é inata, provavelmente herdada dos ancestrais (VIDAL, 2008, pp. 41-43). 
A imagem parece ser cuidadosamente construída, de modo que analogamente pretende apresentar os voos e mesmo os desencontros de diversos personagens-pássaros a serem apresentados ao longo do livro, na busca pela felicidade.

O primeiro conto intitulado "Viagens" constitui a primeira parte do livro e mostra uma relaçâo íntima da narradora com Buenos Aires e com a língua espanhola, lugar que abandonou muito cedo e para onde volta visitando o avô que está morrendo. Os encontros com o avô, que se encontra numa cama, adoecido, em uma casa antiga de um bairro distante e de aspecto degradado pelo tempo, sâo descritos como a recuperaçâo de lembranças fragmentadas de um tempo longínquo, desconcertante, descompassado e inquietante:

Nada daquilo tinha realmente a ver comigo, mas ainda hoje sobrevive em mim como uma zona escura da memória, um ponto de fuga para onde correm medos que náo sei ao certo de onde vêm, nem se algum dia encontrarăo sossego, como se todas as noites me coubesse percorrer sozinha aquele corredor úmido e sombrio, sem saber aonde vai dar (VIDAL, 2008, p. 17).

Os encontros săo concebidos como uma viagem pessoal da narradora ao seu passado e possuem um tom angustiante e irrequieto. A experiência da escrita, aqui precisamente a escrita memorialística, passa a exercer o ato da reflexăo sobre as questôes de deslocamento, espaço, fronteiras e identidade:

[...] Na imagem espacial de um tempo que năo vivi, inscrevo algumas marcas, flertando com a ilusăo de saber de onde eu vim. Como se năo houvesse uma descontinuidade intransponível entre uma vida e outra, entre uma geografia e outra; como se um ser saísse do outro, numa cadeia sucessiva no tempo e no espaço, salto imaginariamente o abismo que existe entre mim e aquele que me gerou (Ibidem, pp. 25-26).

As questōes de língua também săo evidenciadas no texto de Paloma Vidal, relacionadas às questóes de memória afetiva e às indagaçôes sobre o pertencer a um lugar e possuir uma língua materna. Em uma outra viagem descrita nesse mesmo conto, a narradora vai a Londres e conhece um amor argentino em meio a obras de arte brasileiras. O conflito entre os idiomas de ambos (ele querendo aprender português, enquanto ela se diverte com isso porque entende o espanhol, embora ele năo desconfie) acaba por auxiliar o fim do relacionamento, năo permitindo que o idioma inglês torne-se uma possibilidade de ser acrescentado como mais uma língua às memórias da narradora. Ademais, a presença do bilinguismo percorre todo o livro, mas em "Viagens" adquire um acento que ora se soma ao memorialístico, ora o ultrapassa:

Deixo-me levar pelas imagens, năo para reconstruir o que é irreconstruível, mas para tornar visíveis as marcas que essa viagem pode ter deixado em mim e neles. Para entender essa viagem como se entende uma língua estrangeira, nunca absolutamente, sempre com vazios de sentido, expressóes que se perdem, fonemas que se confundem.

$[\ldots]$

Estaremos constituídos de restos de palavras que nos afetam e permanecem em nós, como marcas indestrutíveis, fendas que abrem caminhos definitivos que nunca ficam desertos? (VIDAL, 2008, pp. 29-33). 
Sobre biliguajamento, Walter Mignolo (2003) afirma ser um conceito que vai além da concepçáo da língua como fato ou objeto, constituída e limitada por regras gramaticais, para entender as práticas de leitura e escrita como estratégias que orientam a integraçăo social, a prática cultural e a luta pelo poder:

[...] o linguajamento é o momento no qual uma "língua viva" se descreve como um estilo de vida ("un modo de vivir") na intersecçăo de duas (ou mais) línguas. Nesse ponto, tornam-se evidentes as diferenças entre o bilíngue e o bilinguismo/ bilinguajamento, entre política linguística e linguajamento: o bilinguajamento năo é um estilo de vida, mas uma habilidade (MIGNOLO, 2003, pp. 358-359).

Nesse sentido, pensando na escrita de Paloma Vidal, mais que demonstraçăo de uma capacidade, há na reflexâo sobre o seu estar-entre-linguagens a ideia de um bilinguajamento enquanto "estilo de vida dentro de línguas num mundo transnacional" (MIGNOLO, 2003, p. 370), que conduz a pensarmos numa representaçáo estética da questâo política entre territórios, que, por vezes, desnuda a colonialidade do poder e do saber. Dessa forma, a produçáo do pensamento literário em Mais ao Sul situa-se mais para a colaboraçăo do repensar epistemológico sobre as questóes de língua/linguagem que para uma simples depuraçăo da essência artística no texto. Essas questōes se apresentam no texto literário como configuraçóes inovadoras que apontam para novos mapas linguísticos, que, por sua vez, já năo săo mais os mapas nacionais. Nesse novo contexto, a língua é transfigurada em novas formas de linguajamento, pois, conforme Mignolo (2003), uma língua liminar marcada pelo bilinguajamento ou plurilinguajamento significa o pensar-entre-línguas, pensar na fronteira. Como notamos na obra de Paloma, a emergência do pensar/sentir-se entre duas (ou três, considerando-se a experiência na Inglaterra) línguas apontam para os modernos processos civilizadores, que alteram e ultrapassam as configuraçōes históricas e geopolíticas do ocidentalismo na contemporaneidade.

\section{ESCRITA MEMORIALÍSTICA/AUTOBIOGRÁFICA OU FINGIMENTO DE SI}

Ao buscarmos entender as relaçôes entre memória, escrita de si e deslocamento na constituiçăo de um sujeito fragmentado, por meio da esfera temporal, objetivamos compreender em que medida o "retorno" ao passado pode resgatar a dispersâo do vivido e mesmo do năo vivido (o ficcionalizado), que se apresenta como restos ou ruínas. Dessa forma, procura-se indagar de que modo ou por meio de quais estratégias o "eu" trabalha na recuperaçáo dessas ruínas.

Célia Pedrosa (2011), se reportando a Paul Valéry e a Maurice Blanchot em um ensaio sobre poesia e memória, escreve que o ato de rememorar adquire especial significaçăo no exercício da escrita, identificando uma experiência de crise, ou negatividade, mas conduzindo a uma expectativa de "redençăo". Também nesse sentido, Walter Benjamin em "Sobre o conceito de história", afirma que "(...) a imagem da felicidade está indissoluvelmente ligada à da salvaçăo. O mesmo ocorre com a imagem do passado, que a história transforma em coisa sua. $O$ passado traz consigo um índice misterioso, que o impele à redençăo" (BENJAMIN, 1994, p. 223). Logo, essa fórmula indica que aquele que escreve suas memórias espera que a palavra literária possa reviver o vivido e mesmo o náo vivido, oportunizando o resgate de uma lembrança que năo pode ocorrer fluida como o texto narrativo, que precisa ter as lacunas preenchidas. 
Para a autora, a tensáo gerada por essas duas forças e transposta para a escrita pode se constituir em uma interessante chave para a compreensăo da produçáo literária brasileira nas duas últimas décadas, momento em que sâo frequentemente encenadas as relaçóes do sujeito com a temporalidade e com a memória. Nesse sentido, a prática da memória aparece como objeto de reflexăo poética, e, na obra de Paloma Vidal, se dá pelo viés do autobiografismo ou da escrita de si.

A memória, diante da impossibilidade de reter o tempo e as coisas que nele se perdem, soma-se à convicçâo de que tentar recuperá-los é uma tarefa náo muito prazerosa, pois, como avisam os versos de Pedro Amaral, do poema "Da necessidade do esquecimento": "Lembrar, lembrar.../ É remexer na terra,/ Remoidamente,/ De modo que, por assim fazer,/ Acaba que por fim/ Nâo brota já/ O que havia - de" (AMARAL, 1995, p. 25). Como podemos depreender desses versos, de acordo com Célia Pedrosa, o ato de lembrar é frequentemente associado à tentativa de fixaçâo do homem, que, năo obstante e náo gratuitamente, se correlaciona ao passado como ideia de terra conhecida, espacializada, "portanto, em oposiçăo ao tempo enquanto fluir constante" (PEDROSA, 2011, p. 76).

É a partir das estreitas ligaçōes entre memória e espaço do vivido que escrever se dá sempre como uma tentativa de preencher as intersecçōes das lembranças, isto é, uma tentativa sempre renovada - e ao mesmo tempo fracassada - de tentar dar voz àquilo que náo mais fala, ou que já passou e, portanto, está morto no passado. A escrita da memória assume, por vezes, a estratégia de uma máscara, por detrás da qual o leitor recupera as vozes já "ausentes". Nesse sentido, a escrita autobiográfica, năo pode ser considerada uma depuraçáo dos fatos, mas sim uma re-construçáo das ruínas que habitam a memória, onde, por meio dos espaços vagos entre um destroço e outro, o escritor preenche com material artístico. Esse exercício de reflexăo da própria prática poética aparece em excertos como:

Imagino uma trama de partidas e dela começo a desentranhar minha ficçăo. Partindo mais uma vez, escrevo e me dou conta de que a pura fantasia, com suas possibilidades infinitas, fica aquém dessa história. Ela é real, escavada nos livros e na memória. Escrevo: carreguei marcas através de décadas, acumulei restos de histórias, desagueios na geografia desta cidade. Do mar ao rio, do rio ao mar, de novo ao rio, aqui cheguei, aqui estou. As viagens começam a se escrever quando me deixo levar por uma voz quase perdida que náo é minha. Começo a escrever, tentando năo me deixar afundar no pântano dos relatos familiares. Fico apenas com os retratos e algumas lembranças. A maior parte delas será inventada, numa aventura narrativa que me tira do estado catatônico dos últimos meses e me leva adiante (VIDAL, 2008, pp. 39-40).

Devemos ressalvar que os atos de preencher as lacunas ou inventar as lembranças nas aventuras da rememoraçăo de Paloma Vidal nâo significam que se possa comprometer ou suplantar a verdade histórica do seu relato de vida. Trata-se, no quadro atual da escrita contemporânea, da consciência de que há "múltiplas verdades" e que a eleiçâo ou a unilateralizaçăo da escolha de uma ou outra implica a negaçáo de processo ficcional que náo reconhece a "verdade última" dos fatos. O que se narra será sempre releitura subjetiva, seja do real, seja do imaginário.

É nesse ínterim que a escrita de si de Paloma Vidal abriga relatos de sua própria história, e de outras mulheres (elevando todas as vozes femininas dos contos em um uníssono, por considerarmos que a voz autoral também se inscreve nas demais vozes 
presentes), fragmentos do vivido e do imaginado, reconstruçăo de momentos, de lembranças, ou seja, a elaboraçăo de trabalho imaginativo cujas instâncias de produçâo remetem ao caráter da multiplicidade, da incompletude, e claro, do trabalho inventivo. A palavra resultante desse trabalho delineia também o que a narradora compreende como autobiografia, porque deixa transparecer a todo o tempo a consciência da fragmentaçăo de identidade, da noçáo de pertencimento e do deslocamento. O sentimento de nâo estar em um lugar, mas sim em um entre-lugar é evidenciado na passagem:

Paro depois de escrever "verdadeira origem". O encontro com ele [o amigo de Londres] estilhaçou essa ideia. Até aquele momento eu me equilibrava precariamente entre duas identidades, mas existia um equilíbrio: Buenos Aires era uma imagem ao fundo e o Rio de Janeiro era o primeiro plano, onde se desenrolava a minha vida. Quando me perguntavam sobre a minha nacionalidade, dizia que era uma falsa argentina (VIDAL, 2008, pp. 45-46).

A reflexâo da experiência de escrita, em especial da escrita de si, a busca pela compreensăo de uma identidade que ultrapassa as fronteiras geográficas e culturais ao final do conjunto autobiográfico de "Viagens" revela uma narradora que procura conter a ansiedade entre tantos escombros, que se ocupa em relatar a recuperaçăo de parte de uma história familiar que nunca compartilhou. Com um tom que demonstra angústia e tristeza, a narradora sabe que, independentemente do que possa descobrir, é preciso sobreviver no exílio constante, procurando por um lugar onde possa se sentir em casa:

O que estou fazendo aqui? Precisava de uma explicaçăo, mas năo a dos jornais, a dos noticiários, as dos milhóes de telas espalhadas, inclusive naquele pub, que repetiam as mesmas cenas incansavelmente, as mesmas frases, os mesmos nomes, os mesmos rostos, como se tudo tivesse sido ensaiado, um grande espetáculos com atores anônimos, do qual eu, uma intrusa, inesperadamente fazia parte, sem saber como agir, sem saber o que falar (...) num instante, eu estava jogada no mundo e fazia parte de uma história que nunca teria imaginado como minha. Como sobreviver? A pergunta paira sobre todos os meus gestos. Partindo mais uma vez, escrevo, extraio das palavras que surgem na tela um pouco de energia, o suficiente para mais uma jornada. Sinto os rastros das perguntas dele e me deixo levar ao passado, as imagens que nunca supus ao meu alcance, enquanto se desenha um destino possível, uma nova geografia que poderá me acolher, quem sabe uma outra cidade, um outro rio, muito mais ao sul (VIDAL, 2008, pp. 48-49).

A escrita de Vidal, ao tocar na temática do exílio, apresenta uma estreita relaçâo entre os signos da memória e do deslocamento, que é sintetizada na fala da personagem: "eu estava jogada no mundo e fazia parte de uma história que nunca teria imaginado como minha". Nesse sentido, a memória se apresenta no conto como um receptáculo de todos os rastros e fragmentos do passado. Dessa forma, as discussóes, corporificadas em questionamentos, tais como "o que estou fazendo aqui?" e "Como sobreviver?", por meio da narradora em primeira pessoa, buscam estabelecer um contato íntimo com o leitor, como se estivesse em busca de um interlocutor com quem possa dividir a angústia desse sentimento de năo pertencimento e como que demonstrando que a constituiçâo dos sujeitos perpassa por um repertório de experiências em cacos.

A protagonista desse relato sente a carga de um corpo deslocado, um corpo feminino que, por si só, já se configura pela margem "do fora". Todavia, Mais ao Sul é escrita mediante uma memória que é (re)criada. Nesse sentido, enuncia de marcas autorais 
instigantes que propóem um pacto continuamente renovado, falso ou nâo, entre a ficção e o biografismo.

\section{AS MULHERES DA FICÇÃO E A BUSCA DA FELICIDADE MAIS AO SUL}

Nos demais contos de Mais ao Sul, na segunda parte intitulada "Fantasmas", apresentam-se histórias repletas de afliçâo, relatos de mulheres que, de uma forma ou de outra, aguardam pelo tempo de partir ou de encontrarem a si mesmas, constituindo uma produçăo literária em que a voz feminina se pronuncia com clareza, sem reter sentimentos e sem fazer concessóes. Os contos săo baseados em reminiscências de personagens que tentam se encontrar e se identificar com espaços e outras pessoas, no passado e no presente.

Os contos agrupados em "Fantasmas" problematizam, tal como em "Viagens", a condiçâo de desterritorializaçâo do migrante (ou mesmo a sua multerritorializaçáo) que recorrentemente se dá pelo olhar feminino. As personagens enfrentam a solidăo, o abandono e as consequências de sua "diáspora" pessoal. Nessa perspectiva, buscamos sondar, nesta seçáo, como esse tema, que ocupa atualmente um lugar de destaque na cena contemporânea, provocada pela mundializaçâo da cultura, ganha espaço em obras literárias como a de Paloma Vidal. A autora potencializa os percalços enfrentados pelas personagens femininas e os enfrentamentos desses sujeitos que buscam se aproximar de algum lugar por meio das estratégias de subjetivaçăo dos espaços e da realidade criada.

O que o/esse conjunto de contos transmite de mais forte é uma sensaçăo de falta de chăo que assusta e, ao mesmo tempo, seduz o leitor por meio de uma linguagem furtiva, mas pungente. Os contos assemelham-se a fábulas, em que há sempre um elemento ficcional que deixa o leitor em uma breve "suspensăo". Há sempre algo a ser narrado ou alguém a nos surpreender por trás de uma porta ou de um parágrafo.

A voz feminina revela um olhar oblíquo quando se assume em terceira pessoa, como que a observar a cena de fora do quadro. No deslocamento da voz autoral, que transita entre línguas e espaços diferentes, se constrói o jogo narrativo que domina os diversos contos e impede qualquer obviedade. Para descrevermos os processos poéticos que calcam singularidade à narrativa de Paloma, elegemos dois contos que julgamos significativos por evidenciarem duas facetas distintas: "A aula de tango", e "O retorno".

Em "A aula de tango", os vínculos năo nomeados e silenciosos estabelecem, através do interdito, a sensaçăo crescente de que é a falta que completa o destino dos personagens. As relaçóes entre os personagens do conto sâo narradas em um diálogo entre a protagonista e sua interlocutora, que ouve atentamente. A história contada trata-se da vida cotidiana de uma mulher que se encontra com o filho internado em um hospital, em cujas proximidades há uma escola de dança. Para preencher o tempo vago entre o trabalho e o horário de visita, uma argentina expatriada começa a praticar tango, modalidade que mal conhece e que sempre considerara "coisa de velhos". No decorrer das aulas, a personagem entretece uma relaçăo confusa com um brasileiro que admira ardentemente o país em que ela nasceu. O relacionamento entre os personagens passa a sustentar um falso vínculo de "lugar comum", transformando-se em um trunfo para uma mulher que carece de afetividades. O silenciamento da voz feminina, mediante o 
parceiro de dança, sobre os aspectos de sua vida na terra natal é, muitas vezes, o elemento que rege ou que sustenta as poucas conversaçōes entre ambos:

Ele năo era de fazer perguntas. Sabia que eu tinha um filho. Sabia que eu morava em Copacabana. Devia ter reparado que eu náo usava aliança. Talvez náo soubesse ao certo o que eu fazia, mas sabia, isso sim, que eu era argentina. Era nosso elo. Era meu trunfo. Nâo precisava dizer mais nada. (...) náo precisava contar nada da minha história, da minha vida, do meu país (VIDAL, 2008, p. 74).

Podemos depreender, a partir da fala da narradora, que o manter-se em silêncio por opçâo representava uma estratégia deliberada para manter a ligaçáo com o parceiro, a quem, no entanto, tudo interessava sobre a Argentina. O deslumbramento dele, entretanto, a impressionava:

O silêncio bastava. Eu era discreta e sorria quando ele sentenciava que era desnecessário me explicar isto ou aquilo. Quase sempre se enganava, mas eu năo o contradizia, mantendo meu silêncio e deixando-o falar. Ele mostrava seus conhecimentos: centenas de músicas e letras; quem eram os autores dos tangos e quais eram as melhores gravaçóes; cantores, compositores e orquestras antigas, e também os novos, os grupos que estavam fazendo sucesso em Buenos Aires e os últimos discos lançados. Sabia muito mais do que eu algum dia poderia saber. Seu deslumbramento me era simplesmente impossível (VIDAL, 2008, p. 75).

A economia de histórias/memórias da personagem, no entanto, deixa entrever no diálogo com sua interlocutora um posicionamento de negaçăo de um passado e de uma terra, que se dá por fatores e problemas profundamente sociais, no âmbito da política, da economia e da cultura. Antagonicamente ao saudosismo esperado consensualmente por parte de quem se encontra fora de seu país "de origem" há algum tempo, a voz feminina que narra parece năo desejar tecer qualquer relaçâo memorialística de afetividade com sua terra natal. Seu dilema pessoal, a negaçăo de seu passado, acaba por prejudicar o relacionamento entre os dois colegas de dança:

Ele viajava a Buenos Aires uma vez por ano, no carnaval. Achei graça quando me contou isso. 'Nunca sairia do Rio de Janeiro no carnaval para ir a Buenos Aires', eu disse. 'Aquele calor, aquela umidade. Todo mundo de férias e a cidade vazia'. Ele entăo me olhou desconfiado: 'Há quanto tempo você năo vai a Buenos Aires?' Fiquei constrangida. Tinha falado demais. O que dizer? Que nunca tinha voltado? Que tinha deixado aquela cidade para trás? Agora teria de explicar o que ele năo deveria saber. Havia amargura. Havia tristeza. Havia ódio.

"Ódio?"

Ódio, sim. Ódio de um país que se tornou estranho para mim, que se revelou muito diferente do que tinham me ensinado na escola, martelando aquelas ladainhas sobre amor à pátria. A pátria tinha seus donos e esses donos tinham seus inimigos. Quando me dei conta disso, foi insuportável. Tive que sair. Năo podia explicar isso a ele (Idem, pp. 75-76).

A própria linguagem corporal do tango dispensa o diálogo, todavia, anuncia uma tragédia. A perda de um filho ou ter de cuidar de sua doença traduzem a fragilidade da vida diante de um mundo estranho, de desamparo, e interrompe seus passos. O conto "A aula de tango" tangencia uma perspectiva das questóes de pertencimento, identidade e deslocamento que năo está naturalizada nas representaçóes sobre migraçôes. 
Com perspicaz sutileza, a escritora, que assume a voz da interlocutora da personagem que narra a história, aborda o dilema de mulheres que, como ela, procuram o encontro consigo mesmas mais ao sul.

"O retorno" narra uma viagem em circunstâncias tensas e igualmente aflitivas (a morte do pai da narradora), cheia de reminiscências e que relata/reata a vontade de preencher vazios e construir pontes. As lembranças săo de ordem puramente afetiva e desnudam mais uma das possíveis facetas na relaçăo entre memória-espaço-tempo-identidade. As estratégias assumidas para o exercício do preenchimento das lacunas da rememoraçấo, no entanto, sâo bastante diferentes de "A aula de tango". Neste conto, a personagem preenche as lacunas de uma vivência passada e ameniza a dor da perda do pai criando/recriando lembranças afetivas positivas. O passado é evocado numa tentativa de amenizar a dor da perda:

Năo era a primeira vez que voltava a essa cidade, e provavelmente náo seria a última, mas essa viagem era diferente de qualquer outra. Com a brisa da rua, veio o cheiro familiar que tantas vezes, estando em outros lugares, lhe trouxera a lembrança de sua cidade natal. Sentiu-se em casa. Por um instante, sentiu-se feliz. Mas imediatamente, o que tinha pela frente, o motivo de sua viagem, lhe devolveu a amargura, e sentiu as lágrimas enchendo os seus olhos (VIDAL, 2008, p. 103).

Ao contrário da personagem do conto anterior, a narradora de "O retorno" năo intenciona negar o que deixou para trás, e entrega-se ao relato às lembranças da infância enquanto realiza o trajeto entre o aeroporto e sua antiga residência. $O$ processo de rememoraçăo possui, entretanto, outra estratégia narrativa inscrita: a memória deliberada, seletiva, consciente. Diferentemente do discurso de "Viagens", em que há a narrativa na primeira pessoa do singular, enquanto escrita de si, e do conto "A aula de tango", marcado pelo diálogo conduzido pelo interlocutor para questionar a noçáo de nâo-pertencimento, a narrativa de "O retorno" se manifesta via terceira pessoa: "ela". Esse tom discurso facilita a reflexăo estética sobre o próprio ato narrativo de reconstruir a memória, isto é, discutir o próprio processo literário.

O táxi demora uma hora para percorrer o trajeto. Apoiou a cabeça na janela e fechou os olhos. Lembranças da infância retornavam insistentemente. Em outros momentos de sua vida, ela as havia cultivado com muita ternura, como um resto de alegria no meio das adversidades, mas agora năo conseguia suportar nada do que viesse do passado. Um quintal, um balanço, máos grandes e suaves empurrando suas costas, um sorriso quase ao seu alcance. Preciso objetivar as coisas, disse a si mesma (VIDAL, 2008, p. 104).

Há no relato em terceira pessoa um tom peremptório de luta entre o desejado e o possível. A figuraçăo da viagem como pontes que ligam passado e presente, cada vez mais intransitáveis, exceto que se pratique o exercício de uma memória direcionada, que selecione o que se deve preservar: "A cada viagem, sentia-se mais distante, e o intervalo entre a partida e o retorno se alongava. Voltava agora, mais uma vez, para enterrar seu pai. Preciso objetivar as coisas, repetiu para si mesma" (Ibidem, p. 106).

Em "O retorno" um elemento final aparece, assim como em outros contos de "Fantasmas", e desde a primeira parte do livro, "Viagens", como símbolo do trânsito narrativo da perspectiva autoral: a imagem de um corredor sombrio, que liga o passado ao presente, mencionado na descriçăo de casas antigas, é evocada como uma ponte 
entre dois mundos: "A porta se abriu e, a sua frente, o corredor na penumbra. Deu um passo adiante erguendo a mala e equilibrou-se na soleira da porta, num limiar entre dois mundos" (Ibidem, p. 107).

Temos entăo, que nos contos do livro Mais ao Sul, de Paloma Vidal, a experiência do deslocamento das personagens dá origem a alguns conflitos de identidade ao tempo em que repensa e propóe novos olhares sobre exercício da escrita memorialística. Buenos Aires, Londres e Rio de Janeiro săo algumas cidades que compóem o cenário dessas viagens, isto é, pontes em que transitam as questôes relativas a deslocamento, escrita de si, memória e experiência na escrita. Com astúcia discreta, quase furtiva, Paloma Vidal tece personagens cuja interioridade é um verdadeiro mergulho no questionamento do pertencimento. Em todos os contos narram-se diferentes perspectivas da condiçấo de estrangeiro, o que, por sua vez, provoca o desdobramento de perspectivas e a fragilizaçâo do que se encontrava sedimentado e naturalizado no cotidiano.

O aprofundamento psicológico das personagens é tratado sem afetaçăo ou exagero: a revelaçăo dos dramas é conduzida por uma linguagem econômica, sofisticada, que năo representa qualquer obstáculo para o leitor aproximar-se da dimensăo muito humana de Mais ao Sul. Os relatos se configuram, portanto, em um testemunho denso da humanidade e representam a busca da felicidade mais ao sul, como o fazem os pássaros.

\section{ALGUMAS CONSIDERAÇÕES FINAIS}

O estilo e a brevidade dominantes da narrativa de Paloma Vidal revelam a opçâo pela recusa de tudo que seja espetacular e garantem a singularidade da narrativa. 0 deslocamento, as relaçôes socioespaciais e a reflexăo sobre linguajamento constituem forças centrípetas em Mais ao Sul.

A produtividade artística da escritora reside na habilidade de manejar o simulacro biográfico, na conduçâo de sua experiência na escrita literária e nâo na seduçáo da confidência ou na espontânea despreocupaçăo do testemunho. Em toda a obra, na opçáo pela simplicidade reside o resultado de um difícil trabalho de rejeiçăo de efeitos espetaculares por meio da abordagem do cotidiano que pode ser óbvio, alinhado à năo-óbvia condiçáo da existência.

No entanto, entre o público e o privado, no espaço mundializado porque se move, há uma intimidade ferozmente preservada, ainda que, no mundo contemporâneo, exibir o íntimo parece ser grande atraçăo.

Em torno de obsessôes, através de múltiplas narradoras que se confrontam com a realidade, enfrentando medos e dificuldades, a sensaçăo de năo chegar nunca e de nunca conseguir voltar, Paloma Vidal cria narrativas que parecem dar sequência umas às outras sendo, a cada vez, absolutamente novas. E ao trabalhar com fragmentos memorialísticos, Vidal atua como uma espécie de construtora de identidades, o que para Lévi-Strauss, se assemelha a tarefa de um bricoleur, "que constrói todo o tipo de coisas com o material que tem à máo..." (BAUMAN, 2005, p. 55). 


\section{REFERÊNCIAS}

ABDALA JUNIOR, Benjamin. De Vôos e Ilhas - Literatura e Comunitarismos. Săo Paulo: Ateliê Editorial, 2003.

BAUMAN, Zygmunt. Identidade. Trad. Carlos Alberto Medeiros. Rio de Janeiro: Zahar Editor, 2005.

BENJAMIN, Walter. Obras Escolhidas. Magia e Técnica, Arte e Política. Săo Paulo: Brasiliense, 1994.

CASANOVA, Pascale. As pequenas literaturas. In: A República Mundial das Letras. Trad. Marina Appenzaller. Săo Paulo: Estaçăo Liberdade, pp. 217-251, 2002.

CORRÊA, Mariana Resende; FRANÇA, Cláudia. A figura do bricoleur em práticas artísticas. Visualidades, Goiânia, v. 12, n. 2, pp. 225-239, jul-dez 2014. Disponível em: https:// www.revistas.ufg.br/VISUAL/article/download/34486/18191/. Acesso em: 13 mar. 2020.

HAESBAERT, Rogério. 0 mito da desterritorializaçâo: do "fim dos territórios" à multiterritorialidade. Rio de Janeiro: Bertrand Brasil, 2011.

LÉVI-STRAUSS, Claude. 0 pensamento selvagem. 2 ed. Săo Paulo: Ed. Nacional, 1976.

MIGNOLO, Walter. Histórias locais, projetos globais: colonialidade, saberes subalternos e pensamento liminar. Belo Horizonte: UFMG, 2003.

PEDROSA, Célia. Poesia e memória. In: Ensaios sobre poesia e contemporaneidade. Niterói: Editora da UFF, 2011.

SAYAD, Abdelmalek. A ordem da imigraçăo na ordem das naçôes. In: A imigraçâo ou os paradoxos s auteridade. Trad. Cristina Murachco. Săo Paulo: Editora da USP, pp. 265286, 1998.

VIDAL, Paloma. Mais ao sul. Rio de Janeiro: Língua Geral, 2008.

VIDAL, Palom. As duas măos. Rio de Janeiro: 7Letras, 2003.

Recebido em 25/05/2020

Aceito em 06/07/2020 